\title{
Ki-67 as an independent prognostic factor in an unselected cohort of patients with ovarian cancer: Results of an explorative, retrospective study
}

\author{
MARCO JOHANNES BATTISTA ${ }^{1}$, NINA MANTAI ${ }^{1}$, ISABEL SICKING ${ }^{1}$, CRISTINA COTARELO $^{2}$, \\ VERONIKA WEYER ${ }^{3}$, ANTJE LEBRECHT ${ }^{1}$, CHRISTINE SOLBACH $^{1}$ and MARCUS SCHMIDT ${ }^{1}$ \\ Departments of ${ }^{1}$ Gynaecology and Obstetrics and ${ }^{2}$ Pathology, University Medical Centre Mainz; ${ }^{3}$ Institute of \\ Medical Biostatistics, Epidemiology and Informatics, University Medical Centre Mainz, D-55131 Mainz, Germany
}

Received November 30, 2013; Accepted January 22, 2014

DOI: 10.3892/or.2014.3079

\begin{abstract}
The identification of prognostic markers has clinical implications in epithelial ovarian carcinoma (EOC). Here, we studied markers for proliferation (Ki-67), endocrine regulation [progesterone receptor (PR), estrogen receptor (ER)], and invasion [urokinase-type plasminogen activator (uPA) and plasminogen activator inhibitor (PAI-1)]. All patients with available follow-up information and EOC tissue, who were treated at our institution between 1997 and 2004, were enrolled in the present study. Expression of Ki-67, PR and ER was determined by immunohistochemical analyses. uPA and PAI-1 antigen levels were determined using enzyme-linked immunosorbent assays. One hundred and eight patients entered the present study. The median follow-up time was 43.3 (range 11.4-68.0) months. In multivariable Cox regression analyses, Ki-67 expression showed an independent negative impact on disease-free survival (DFS) and overall survival (OS) [hazard ratio (HR) for DFS, 11.5 ; 95\% confidence interval (CI), 2.6449.7; $\mathrm{p}=0.001$ and $\mathrm{HR}$ for OS, $21.2 ; 95 \% \mathrm{CI}, 9.9-113.1 ; \mathrm{p}<0.001]$. After cut-off optimization, PR expression showed an independent positive impact on prognosis (HR for DFS, 0.15 ; 95\% CI, 0.03-0.68; $\mathrm{p}=0.014$ and HR for OS, 0.13 ; $95 \% \mathrm{CI}, 0.03-0.68$; $\mathrm{p}=0.016$ ). Furthermore, postoperative residual tumor burden and completeness of chemotherapy determined the prognosis. ER, uPA and PAI-1 were not associated with survival. PR and ER, and postoperative residual tumor burden and tumor stage showed a strong correlation in an explorative Spearman's rank correlation coefficient (rho $=0.759$ and $\mathrm{rho}=0.426$, respectively). Ki-67 and cut-off optimized PR are independently associated with the prognosis of EOC. Further prospective studies are warranted to confirm these associations and to elucidate the underlying mechanisms.
\end{abstract}

Correspondence to: Dr Marco Johannes Battista, Department of Gynaecology and Obstetrics, University Medical Centre Mainz, Langenbeckstrasse 1, D-55131 Mainz, Germany

E-mail: battist@uni-mainz.de

Key words: ovarian cancer, Ki-67, progesterone receptor, prognosis

\section{Introduction}

Tumor stage, postoperative residual tumor burden, histological type and histological grade are the most important clinicalpathological factors related to the prognosis of patients with epithelial ovarian cancer (EOC) (1). However, patients with comparable risk factors may have different prognoses underlying the need for further prognostic factors (2).

Uncontrolled cellular proliferation is one of the definitive characteristics of malignancies (3). Mitotic count is a traditional and practical method to determine proliferative activity, but is hampered by several conflicting factors (4). Alternatively, immunohistochemical detection of proliferating cells may help to determine the proliferative potential of a tumor. Ki-67 is expressed during all active phases of the cell cycle, and the monoclonal Ki-67 antibody MIB-1 binds to the nuclear Ki-67 antigen (5). Growing evidence underlines that high expression of $\mathrm{Ki}-67$ indicates poor prognosis in several types of cancers (6-9). In EOC, however, Ki-67 has not yet been fully established as a reliable prognostic factor thus showing the need for further investigation.

Nulliparity and infertility as hormonal risk factors have been identified in regards to the development of EOC in epidemiological studies, while pregnancy and oral contraceptives appear to protect from the disease (1). This has led to further investigation of the role of the two steroid hormones estrogen and progesterone and their receptors in EOC $(10,11)$. Even if growing evidence supports the theory that the progesterone receptor (PR) has a favorable impact on the prognosis of EOC in contrast to the estrogen receptor (ER), the available literature is contradictory (11-15).

The invasion in surrounding tissue is another definitive characteristic of malignancies (3). Urokinase-type plasminogen activator (uPA) catalyzes the conversion of plasminogen to plasmin (16). Plasmin leads to the degradation of the extracellular matrix and basement membrane (16). Plasminogen activator inhibitor-1 (PAI-1) inhibits the activation of uPA (17). However, PAI-1 modulates cell migration and induces tumor proliferation by activation of intracellular signal transduction (17). Thereby, uPA and PAI-1 are strongly implicated as a promoter in various solid tumors $(16,17)$. 


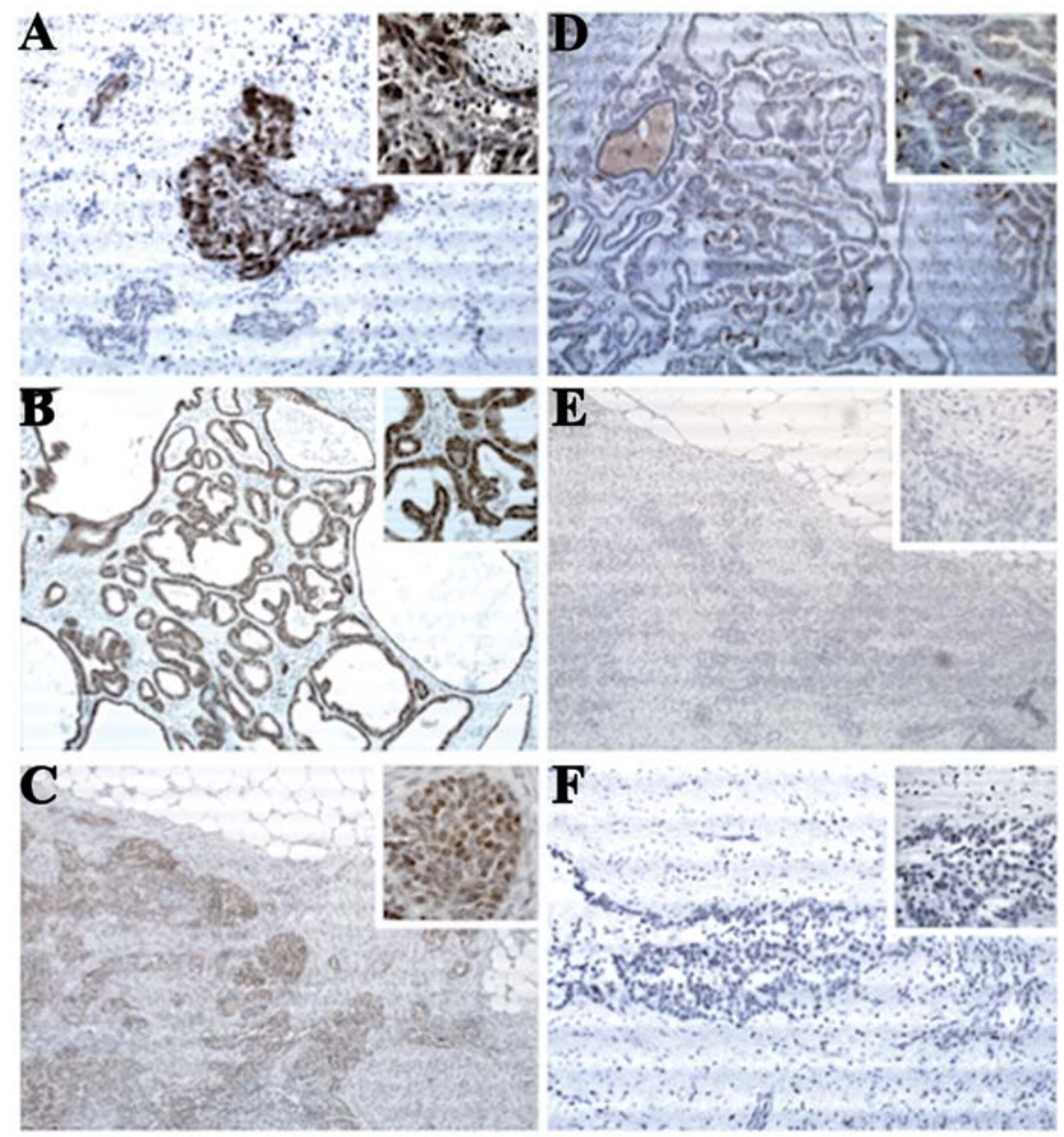

Figure 1. Representative images of immunostaining against (A and D) Ki-67, (B and E) PR and (C and F) ER. (A) Ki-67-positive infiltrate in $>50 \%$ of the cancer cells in a papillary serous EOC, histological grade 3 (original magnification, x100; inset, x400). (B) Strong PR-positive infiltrate in $>80 \%$ of the cancer cells in an endometrioid EOC, histological grade 1 (original magnification, x100; inset, x400). (C) Strong ER-positive infiltrate in $>80 \%$ of the cancer cells in a papillary serous EOC, histological grade 2 (original magnification, x100; inset, $x 400$ ). (D) Ki-67-positive infiltrate in $<6 \%$ of the cancer cells in a papillary serous EOC, histological grade 1 (original magnification, x100; inset, x400). (E) No PR-positive infiltrate in a papillary serous EOC, histological grade 2 (original magnification, $\mathrm{x} 100$; inset, $\mathrm{x} 400$ ). (F) No ER-positive infiltrate in a papillary serous EOC, histological grade 3 (original magnification, x100; inset, $\mathrm{x} 400)$. PR, progesterone receptor; ER, estrogen receptor; EOC, epithelial ovarian carcinoma.

Current literature concerning uPA and PAI-1 in EOC is still controversial $(18,19)$.

In this explorative, retrospective study, we examined possible associations between Ki-67, PR, ER, uPA, PAI-1 and overall survival (OS) and disease-free survival (DFS) in an unselected consecutive cohort of patients with EOC.

\section{Materials and methods}

Patients and tissue samples. We searched the archives for all patients with EOC who underwent primary surgery during the time period of 1997 and 2004. Patients entered the present study when formalin-fixed paraffin-embedded (FFPE) tissue or aliquots of fresh tissue were available. Follow-up was conducted by writing letters to patients or their physicians, phoning them, and by checking the patient records until November of 2012. We documented i) death from EOC or from other reasons unrelated to cancer and ii) recurrence of disease, which included metastasis, local relapse and secondary tumors. Patient charts were reviewed to collect data regarding age at diagnosis, histological type, tumor stage of disease according to the guidelines of the
International Federation of Gynecology and Obstetrics (FIGO) and lymph node status. We compared EOC with high-grade serous carcinoma vs. other types in the analysis of histological type. The amount of residual disease after primary surgery was registered as R0, R1 and R2. Completed chemotherapy was defined as 6 courses of platinum-based monotherapy in early EOC or as platinum-based combination with paclitaxel for patients being treated after 2000 or with cyclophosphamide for the rest of the patients. The present study was approved by the Research Ethics Committee of the University Medical Centre Mainz, Germany. Informed consent was obtained from all patients. All specimens were handled according to the ethical and legal standards.

Immunohistochemistry and evaluation of staining of Ki-67, PR and $E R$. Serial sections of formalin-fixed slices were stained with monoclonal MIB-1 antibodies (clone MIB-1; Dako, Glostrup, Denmark) as previously described (20) (Fig. 1). In accordance with previous reports on Ki-67 staining, overexpression was defined when $>20 \%$ of the cancer cells were stained $(6,21)$. 
Serial sections of formalin-fixed slices were stained with either monoclonal ER antibodies (clone 1D5) or monoclonal PR antibodies (clone PgR 636) (both from Dako), as previously described (22) (Fig. 1). Expression of ER and PR was assessed using an immunoreactive score defined by the product of a proportion ( 0 , none; $1,<10 \% ; 2,10-50 \% ; 3,51-80 \%$; $4,81-100 \%)$ and an intensity score ( 0 , no staining; 1 , weak; 2 , moderate; 3 , strong) (23).

Enzyme-linked immunosorbent assay (ELISA) of uPA and $P A I-1$. The protein levels of UPA and PAI-1 were determined as previously described by Steiner et al using commercially available kits (Imibind tissue uPA ELISA kit product no. 894, and Imibind tissue PAI-1 ELISA kit product no. 82; American Diagnostica Inc., Greenwich, CT, USA) (24).

Statistical analyses. Statistical analyses were performed using the SPSS statistical software program, version 21.0 (SPSS Inc., Chicago, IL, USA). Patient characteristics were expressed as absolute and relative numbers or as median with their quartiles. Cut-off optimization was performed for PR and ER using univariable Cox regression analyses. The Cox proportional hazard regression model was used to evaluate the effect of explorative variables on DFS and OS. First, univariable Cox regression analyses were performed for every single variable. Secondly, variables with a p-value $<0.05$ entered the multivariable Cox regression analysis with a variable selection via backward elimination. All associations were expressed as hazard ratios (HR) with their $95 \%$ confidence intervals (CI) and p-values. Kaplan-Meier estimations were performed to describe survival rates. Correlations between the proliferation markers were analyzed with the Spearman's rank correlation coefficient. As this was an explorative study, no adjustments for multiple testing were carried out. The statistical tests were carried out for illustrative purposes rather than hypothesis testing. p-values were provided for descriptive reasons only and should be interpreted with caution and in connection with effect estimates.

\section{Results}

A total of 162 patients were screened. Thirty-four and 18 patients were excluded due to missing tissue samples and inappropriate follow-up information, respectively. Two patients suffered from a borderline tumor. Thereby, 108 patients entered the present study. The median follow-up time was 43.3 (range 11.4-68.0) months. Seventy-nine recurrences and 66 deaths occurred. The characteristics of the patients are presented in Table I.

Immunohistochemical analysis and ELISA were performed on 103 and 87 EOC tissues, respectively. In this cohort the optimal cut-off for PR was 6 (data not shown). For ER no meaningful cut-off was detectable (data not shown). In analogy to PR, patients with a score of 6 or higher for ER were considered positive. Positive-staining of Ki-67, PR and ER was observed in $73.8,14.3$ and $19.0 \%$, respectively. The median (quartiles) of uPA and PAI-1 were 3.0 (1.0-6.0) and 21.0 (12.056.3), respectively (Table I).

In univariable and mulitivariable Cox regression analysis Ki-67 and PR were associated with DFS and OS (Table II). ER,
Table I. Patient characteristics $(\mathrm{n}=108)$.

\begin{tabular}{lc}
\hline Parameter & $\mathrm{n}(\%)$ \\
\hline Mean age \pm SD (years) & $61.7 \pm 11.4$ \\
Tumor stage (FIGO) & \\
I & $27(25.0)$ \\
II & $4(3.7)$ \\
III & $66(61.1)$ \\
IV & $11(10.2)$
\end{tabular}

Histological grade $(n=103)$

G1

$\mathrm{G} 2$

G3

Histological type $(n=107)$

Serous

Mucinous

Endometrioid

Clear cell

$6 \quad(5.6)$

Undifferentiated

$10 \quad(9.3)$

Mixed

$10(9.3)$

Postoperative residual tumor burden $(n=105)$

R0

$26(24.1)$

$21(19.4)$

R1

$58(53.7)$

Chemotherapy $(n=97)$

Complete

$70(72.2)$

Incomplete

27 (27.8)

Prognostic factors

$\mathrm{Ki}-67^{+}$

$76(73.8)$

$\mathrm{PR}^{+}$

15 (14.3)

$\mathrm{ER}^{+}$

$20(19.0)$

uPA

$3(1.0-6.0)^{\mathrm{a}}$

PAI-1

$21(12.0-56.3)^{\mathrm{a}}$

SD, standard deviation. FIGO, International Federation of Gynecology and Obstetrics; G, histological grade; PR, progesterone receptor; ER, estrogen receptor; uPA, urokinase-type plasminogen activator; PAI-1, plasminogen activator inhibitor $1 .{ }^{a}$ Median (quartiles) of uPA and PAI-1.

uPA and PAI-1 were not associated with prognosis (Table II). Tumor stage, histological type, histological grade, postoperative residual tumor burden and completeness of chemotherapy were associated with DFS and OS in univariable Cox regression analysis (Table II). However, in multivariable Cox regression analysis only postoperative residual tumor burden and completeness of chemotherapy were associated with DFS and OS (Table II).

Kaplan-Meier plots demonstrated the influence of Ki-67 and PR on the 5-year DFS rates (55.1 vs. 24.9\%, $\mathrm{p}=0.011$ and 60.0 vs. $27.6 \%, \mathrm{p}=0.011$, respectively) and on the 5-year OS rates $(72.8$ vs. $30.3 \%, \mathrm{p}=0.005$ and 65.2 vs. $37.1 \%, \mathrm{p}=0.023$, respectively) (Fig. 2). 

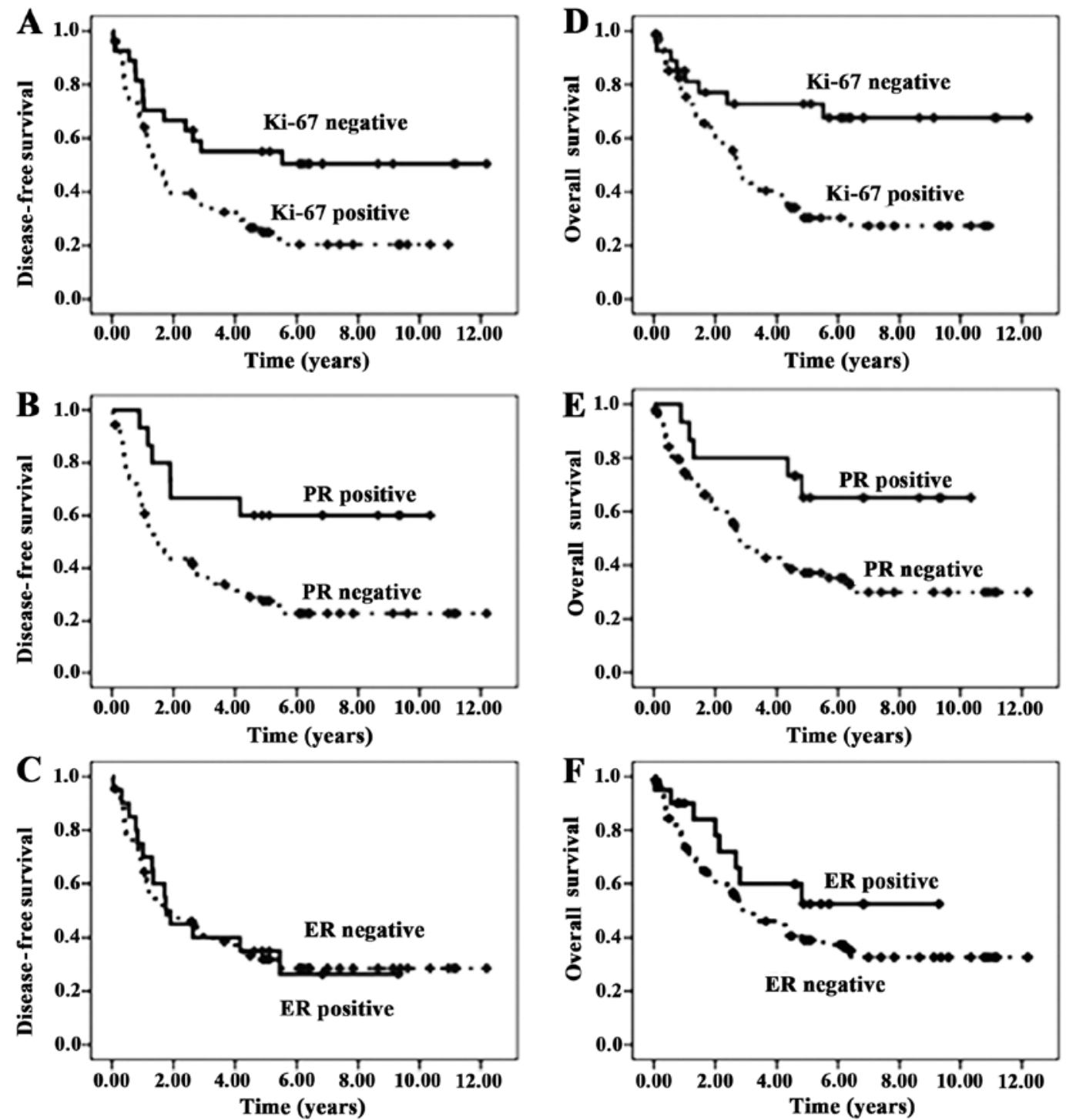

Figure 2. Kaplan-Meier plots of (A and D) Ki-67, (B and E) PR and (C and F) ER, for (A-C) DFS and (D-F) OS. PR, progesterone receptor; ER, estrogen receptor; DFS, disease-free survival; OS, overall survival.

Explorative correlation analyses revealed a statistically relevant correlation between postoperative residual tumor burden and tumor stage, between PR and ER, between completeness of chemotherapy and age, between histological grade and tumor stage and between histological grade and postoperative tumor burden, respectively (all p-values $<0.001$ ) (Table III). Furthermore, correlation analyses showed a strong correlation between postoperative residual tumor burden and tumor stage and between PR and ER, respectively (rho >0.4) (Table III).

\section{Discussion}

The present study examined the influence of the expression of Ki-67, PR and ER as well as uPA/PAI-1 on the prognosis of an unselected cohort of 108 patients with EOC utilizing Kaplan-Meier estimations as well as univariable and multivariable Cox regression analyses.

There is a growing body of evidence for a prognostic role of $\mathrm{Ki}-67$ in EOC. In several reports, patients with high $\mathrm{Ki}-67$ were found to have a less favorable 5 -year survival $(8,25)$.
These patients were also more likely to have other poor prognostic factors, including advanced tumor stage $(21,26)$, higher tumor grade $(21,27)$ and postoperative residual tumor burden (27). However, other studies were not able to show significant associations between Ki-67 and tumor stage $(6,28)$, histological type $(21,25,27)$ and tumor grade $(6,28)$. In the present study, patients with high Ki-67 showed a much shorter OS and DFS compared to EOC cases with low Ki-67 in the univariable and multivariable analyses. The 5-year overall survival rate for patients with a low Ki-67 was more than two times higher when compared to Ki-67-positive tumors. This relation is similar to the findings of other studies $(6,21,27,28)$. However, the high HR of Ki-67 on DFS and OS and their broad $95 \%$ CI can be regarded as a result of the small number of events in this relatively small cohort with 108 patients and should thereby be interpreted with caution. In the present study, Ki-67 correlated only weakly with tumor stage and with postoperative residual tumor burden. Surprisingly, no association was detected between $\mathrm{Ki}-67$ and histological grade or other clinicopathological factors. This may be due to the fact, 
Table II. Univariable and multivariable Cox regression analyses for disease-free and overall survival.

A, Disease-free survival

\begin{tabular}{|c|c|c|c|c|}
\hline \multirow[b]{2}{*}{ Parameter } & \multicolumn{2}{|c|}{ Univariable } & \multicolumn{2}{|c|}{ Multivariable } \\
\hline & HR $(95 \% \mathrm{CI})$ & P-value & HR $(95 \% \mathrm{CI})$ & P-value \\
\hline Age (years) & $1.0(0.99-1.03)$ & 0.536 & - & - \\
\hline Tumor stage (FIGO) & $2.7(2.03-3.62)$ & $<0.001$ & $1.3(0.77-2.21)$ & 0.328 \\
\hline Histological grade & $1.8(1.24-2.51)$ & 0.002 & $0.8(0.48-1.20)$ & 0.239 \\
\hline Histological type & $0.5(0.29-0.77)$ & 0.002 & $0.6(0.32-1.18)$ & 0.146 \\
\hline Postoperative residual tumor burden & $5.1(3.20-8.12)$ & $<0.001$ & $5.5(3.22-9.23)$ & $<0.001$ \\
\hline Completeness of chemotherapy & $2.1(1.28-3.54)$ & 0.004 & $1.8(1.02-3.11)$ & 0.043 \\
\hline Ki-67 & $2.2(1.18-3.98)$ & 0.013 & $11.5(2.64-49.7)$ & 0.001 \\
\hline PR & $0.4(0.15-0.81)$ & 0.015 & $0.15(0.03-0.68)$ & 0.014 \\
\hline ER & $0.9(0.52-1.69)$ & 0.841 & - & - \\
\hline uPA & $1.0(0.95-1.06)$ & 0.850 & - & - \\
\hline PAI-1 & $1.0(0.99-1.01)$ & 0.889 & - & - \\
\hline
\end{tabular}

B, Overall survival

\begin{tabular}{|c|c|c|c|c|}
\hline \multirow[b]{2}{*}{ Parameter } & \multicolumn{2}{|c|}{ Univariable } & \multicolumn{2}{|c|}{ Multivariable } \\
\hline & $\mathrm{HR}(95 \% \mathrm{CI})$ & P-value & $\operatorname{HR}(95 \% \mathrm{CI})$ & P-value \\
\hline Age (years) & $1.0(0.99-1.04)$ & 0.223 & - & - \\
\hline Tumor stage (FIGO) & $2.7(1.95-3.83)$ & $<0.001$ & $1.2(0.64-2.34)$ & 0.574 \\
\hline Histological grade & $1.8(1.18-2.60)$ & 0.005 & $0.7(0.44-1.23)$ & 0.245 \\
\hline Histological type & $0.6(0.37-1.04)$ & 0.071 & - & - \\
\hline Postoperative residual tumor burden & $4.4(2.70-7.26)$ & $<0.001$ & $5.3(2.85-9.85)$ & $<0.001$ \\
\hline Completeness of chemotherapy & $2.7(1.55-4.70)$ & $<0.001$ & $2.4(1.30-4.50)$ & 0.005 \\
\hline $\mathrm{Ki}-67$ & $2.8(1.33-5.98)$ & 0.007 & $21.1(9.9-113.1)$ & $<0.001$ \\
\hline PR & $0.4(0.14-0.90)$ & $\mathbf{0 . 0 3 0}$ & $0.13(0.03-0.68)$ & 0.016 \\
\hline ER & $0.6(0.28-1.26)$ & 0.176 & - & - \\
\hline uPA & $0.9(0.93-1.06)$ & 0.810 & - & - \\
\hline PAI-1 & $1.0(0.99-1.01)$ & 0.728 & - & - \\
\hline
\end{tabular}

Bold font indicates that statistical significance was achieved. HR, hazard ratio; CI, confidence interval; FIGO, International Federation of Gynecology and Obstetrics; PR, progesterone receptor; ER, estrogen receptor; uPA, urokinase-type plasminogen activator; PAI-1, plasminogen activator inhibitor 1 .

that the predictive value of histological grade was hampered by several conflicting factors such as interobserver variability and the co-existence of different definitions (29). On the other hand, this supports our finding that Ki-67 behaves as an independent prognostic marker in patients with EOC.

The available literature concerning the prognostic impact of PR and ER on the prognosis of EOC is contradictory. Several studies report no association between the expression of $\mathrm{PR}$ and the survival of EOC patients $(12,13)$, while other studies report that a higher PR status indicates a favorable prognosis $(14,15)$. This may rely on different analytical methods, cut-off and scoring systems $(12,14,15,30)$. Furthermore, the inclusion criteria of several steroid receptor expression studies for EOC are broad so that even patients with certain histological subtypes, histological grade or tumor stage are included $(30,31)$. However, a meta-analysis conducted by Zhao et al (11) found that higher levels of PR predicted favorable prognosis whereas expression of ER did not influence prognosis. The results from our study are in concordance with these results. In the present study, PR and ER showed a moderate correlation. This finding is in line with in vitro results and clinical results $(30,32,33)$. Furthermore, the expression of PR correlated only weakly with tumor stage or histological grade or histological type or postoperative residual tumor burden supporting the theory that PR represents an independent prognostic marker.

Notably, expression of UPA and PAI-1 was not associated with prognosis or other clinicopathological factors in this cohort of patients. These findings confirm the results of a study 
Table III. Explorative Spearman's rank coefficient analyses of all clinicopathological factors.

\begin{tabular}{|c|c|c|c|c|c|c|c|c|c|c|}
\hline & Age & $\begin{array}{l}\text { Tumor } \\
\text { stage } \\
\text { (FIGO) }\end{array}$ & $\begin{array}{l}\text { Histological } \\
\text { grade }\end{array}$ & $\begin{array}{l}\text { Histological } \\
\text { type }\end{array}$ & $\begin{array}{l}\text { Post- } \\
\text { operative } \\
\text { residual } \\
\text { tumor } \\
\text { burden }\end{array}$ & $\begin{array}{c}\text { Completeness } \\
\text { of chemo- } \\
\text { therapy }\end{array}$ & Ki-67 & PR & ER & uPA \\
\hline Tumor stage (FIGO) & $\begin{array}{l}0.028 \\
0.777\end{array}$ & - & & & & & & & & \\
\hline Histological grade & $\begin{array}{r}-0.051 \\
0.609\end{array}$ & $\begin{array}{r}0.379 \\
<0.001\end{array}$ & - & & & & & & & \\
\hline Histological type & $\begin{array}{l}0.026 \\
0.792\end{array}$ & $\begin{array}{r}-0.275 \\
0.004\end{array}$ & $\begin{array}{r}-0.261 \\
0.004\end{array}$ & - & & & & & & \\
\hline $\begin{array}{l}\text { Postoperative residual } \\
\text { tumor burden }\end{array}$ & $\begin{array}{l}0.140 \\
0.154\end{array}$ & $\begin{array}{r}0.759 \\
<0.001\end{array}$ & $\begin{array}{c}0.365 \\
<0.001\end{array}$ & $\begin{array}{r}-0.255 \\
0.009\end{array}$ & - & & & & & \\
\hline $\begin{array}{l}\text { Completeness of } \\
\text { chemotherapy }\end{array}$ & $\begin{array}{r}0.380 \\
<0.001\end{array}$ & $\begin{array}{l}0.105 \\
0.304\end{array}$ & $\begin{array}{r}-0.039 \\
0.714\end{array}$ & $\begin{array}{l}0.210 \\
0.041\end{array}$ & $\begin{array}{l}0.236 \\
0.021\end{array}$ & - & & & & \\
\hline Ki-67 & $\begin{array}{l}0.087 \\
0.383\end{array}$ & $\begin{array}{l}0.201 \\
0.041\end{array}$ & $\begin{array}{l}0.194 \\
0.055\end{array}$ & $\begin{array}{r}-0.142 \\
0.157\end{array}$ & $\begin{array}{l}0.228 \\
0.022\end{array}$ & $\begin{array}{l}0.121 \\
0.247\end{array}$ & - & & & \\
\hline PR & $\begin{array}{r}-0.154 \\
0.116\end{array}$ & $\begin{array}{r}-0.303 \\
0.002\end{array}$ & $\begin{array}{l}-0.229 \\
0.022\end{array}$ & $\begin{array}{l}0.205 \\
0.038\end{array}$ & $\begin{array}{r}-0.325 \\
0.001\end{array}$ & $\begin{array}{r}-0.130 \\
0.208\end{array}$ & $\begin{array}{r}-0.004 \\
0.996\end{array}$ & - & & \\
\hline ER & $\begin{array}{r}-0.046 \\
0.644\end{array}$ & $\begin{array}{r}-0.057 \\
0.564\end{array}$ & $\begin{array}{l}-0.165 \\
0.101\end{array}$ & $\begin{array}{l}0.162 \\
0.103\end{array}$ & $\begin{array}{r}-0.036 \\
0.718\end{array}$ & $\begin{array}{l}0.053 \\
0.612\end{array}$ & $\begin{array}{r}-0.098 \\
0.324\end{array}$ & $\begin{array}{r}0.426 \\
<0.001\end{array}$ & - & \\
\hline uPA & $\begin{array}{l}0.161 \\
0.137\end{array}$ & $\begin{array}{l}0.187 \\
0.083\end{array}$ & $\begin{array}{l}0.124 \\
0.269\end{array}$ & $\begin{array}{r}-0.226 \\
0.037\end{array}$ & $\begin{array}{l}0.189 \\
0.085\end{array}$ & $\begin{array}{r}-0.071 \\
0.539\end{array}$ & $\begin{array}{r}-0.043 \\
0.699\end{array}$ & $\begin{array}{r}-0.067 \\
0.545\end{array}$ & $\begin{array}{r}-0.088 \\
0.424\end{array}$ & - \\
\hline PAI-1 & $\begin{array}{l}0.018 \\
0.867\end{array}$ & $\begin{array}{l}0.172 \\
0.109\end{array}$ & $\begin{array}{l}0.140 \\
0.207\end{array}$ & $\begin{array}{r}-0.040 \\
0.715\end{array}$ & $\begin{array}{l}0.117 \\
0.286\end{array}$ & $\begin{array}{r}-0.019 \\
0.869\end{array}$ & $\begin{array}{l}0.114 \\
0.302\end{array}$ & $\begin{array}{r}-0.111 \\
0.308\end{array}$ & $\begin{array}{r}-0.181 \\
0.095\end{array}$ & $\begin{array}{l}0.151 \\
0.163\end{array}$ \\
\hline
\end{tabular}

Bold font indicate a p-value $<0.001$. Italics indicate a correlation being at least moderate (rho $>0.4$ ). FIGO, International Federation of Gynecology and Obstetrics; PR, progesterone receptor; ER, estrogen receptor; uPA, urokinase-type plasminogen activator; PAI-1, plasminogen activator inhibitor 1 .

by van der Burg et al although uPA and PAI-1 levels were higher in ovarian cancer patients when compared to the levels in benign lesions (18). On the contrary, other studies showed an independent association of the overexpression of UPA and PAI-1 with impaired prognosis in EOC $(19,34)$. However, to the best of our knowledge these results have not yet been validated.

Unfortunately, to date, no meaningful therapeutic benefit results out of the growing, but partially conflicting body of evidence on endocrine regulation and proliferation of EOC. Endocrine therapy, e.g. with the aromatase inhibitor letrozole or with tamoxifen, has shown small clinical benefit only in subgroups of patients with EOC $(35,36)$. Even if it is selfevident that antiproliferative chemotherapy is more effective in tumors which are highly proliferative, possibly due to an increased chemosensitivity, the treatment decision for adjuvant chemotherapy mostly relies on the tumor stage and not on proliferation (37). The decision regarding chemotherapy is influenced by the histological grade only in the early stages. However, to date, no single validated prognostic biomarker is available for patients with EOC. This may depend on the multifarious demands for biomarkers being regarded as valuable prognostic factors. The proposed biomarker should provide specificity, sensitivity and should be prognostic, reproducible, independent and validated. Thereby, the introduction of a new biomarker may facilitate a simpler and more consistent method with which to stratify patients. Possibly, this may improve our understanding of carcinogenesis, tailor adjuvant therapy and improve prognosis. At present, the significant and already established prognostic factors are clinicopathological variables such as postoperative residual tumor burden, tumor stage, histological type, histological grade, completeness of chemotherapy and age.

In conclusion, we demonstrated in an explorative, retrospective study that $\mathrm{Ki}-67$ is an independent prognostic marker for patients with EOC. After cut-off optimization, PR also functioned as an independent prognostic marker. ER, uPA and PAI-1 were not associated with prognosis. Clearly, these findings should be validated in additional prospective studies.

\section{Acknowledgements}

Sections of the results presented in the present study derived from the doctoral thesis of Ms. Nina Mantai. 


\section{References}

1. Cannistra SA: Cancer of the ovary. N Engl J Med 351: 2519-2529, 2004.

2. Gadducci A, Cosio S, Tana R and Genazzani AR: Serum and tissue biomarkers as predictive and prognostic variables in epithelial ovarian cancer. Crit Rev Oncol Hematol 69: 12-27, 2009.

3. Hanahan D and Weinberg RA: Hallmarks of cancer: the next generation. Cell 144: 646-674, 2011.

4. Linden MD, Torres FX, Kubus J and Zarbo RJ: Clinical application of morphologic and immunocytochemical assessments of cell proliferation. Am J Clin Pathol 97 (Suppl 1): S4-S13, 1992.

5. Cattoretti G, Becker MH, Key G, et al: Monoclonal antibodies against recombinant parts of the Ki-67 antigen (MIB 1 and MIB 3) detect proliferating cells in microwave-processed formalin-fixed paraffin sections. J Pathol 168: 357-363, 1992.

6. Garzetti GG, Ciavattini A, Goteri G, et al: Ki67 antigen immunostaining (MIB 1 monoclonal antibody) in serous ovarian tumors: index of proliferative activity with prognostic significance. Gynecol Oncol 56: 169-174, 1995.

7. Viale G, Giobbie-Hurder A, Regan MM, et al: Prognostic and predictive value of centrally reviewed $\mathrm{Ki}-67$ labeling index in postmenopausal women with endocrine-responsive breast cancer: results from Breast International Group Trial 1-98 comparing adjuvant tamoxifen with letrozole. J Clin Oncol 26 : 5569-5575, 2008.

8. Kritpracha K, Hanprasertpong J, Chandeying V, Dechsukhum C and Geater A: Survival analysis in advanced epithelial ovarian carcinoma in relation to proliferative index of MIB-1 immunostaining. J Obstet Gynaecol Res 31: 268-276, 2005.

9. Margulis V, Lotan Y, Karakiewicz PI, et al: Multi-institutional validation of the predictive value of Ki-67 labeling index in patients with urinary bladder cancer. J Natl Cancer Inst 101: $114-119,2009$.

10. Scambia G, Ferrandina G, Agostino GD, et al: Oestrogen and progesterone receptors in ovarian carcinoma. Endocr Relat Cancer 3: 293-301, 1998.

11. Zhao D, Zhang F, Zhang W, He J, Zhao Y and Sun J: Prognostic role of hormone receptors in ovarian cancer: a systematic review and meta-analysis. Int J Gynecol Cancer 23: 25-33, 2013.

12. Bizzi A, Codegoni AM, Landoni F, et al: Steroid receptors in epithelial ovarian carcinoma: relation to clinical parameters and survival. Cancer Res 48: 6222-6226, 1988.

13. Geisler JP, Wiemann MC, Miller GA and Geisler HE: Estrogen and progesterone receptor status as prognostic indicators in patients with optimally cytoreduced stage IIIc serous cystadenocarcinoma of the ovary. Gynecol Oncol 60: 424-427, 1996.

14. Lee P, Rosen DG, Zhu C, Silva EG and Liu J: Expression of progesterone receptor is a favorable prognostic marker in ovarian cancer. Gynecol Oncol 96: 671-677, 2005.

15. Sinn BV, Darb-Esfahani S, Wirtz RM, et al: Evaluation of a hormone receptor-positive ovarian carcinoma subtype with a favourable prognosis by determination of progesterone receptor and oestrogen receptor $1 \mathrm{mRNA}$ expression in formalin-fixed paraffin-embedded tissue. Histopathology 59: 918-927, 2011.

16. Andreasen PA, Kjøller L, Christensen L and Duffy MJ: The urokinase-type plasminogen activator system in cancer metastasis: a review. Int J Cancer 72: 1-22, 1997.

17. Nykjaer A, Conese M, Christensen EI, et al: Recycling of the urokinase receptor upon internalization of the uPA:serpin complexes. EMBO J 16: 2610-2620, 1997.

18. van der Burg ME, Henzen-Logmans SC, Berns EM, van Putten WL, Klijn JG and Foekens JA: Expression of urokinase-type plasminogen activator (uPA) and its inhibitor PAI-1 in benign, borderline, malignant primary and metastatic ovarian tumors. Int J Cancer 69: 475-479, 1996.

19. Konecny G, Untch M, Pihan A, et al: Association of urokinase-type plasminogen activator and its inhibitor with disease progression and prognosis in ovarian cancer. Clin Cancer Res 7 $1743-1749,2001$
20. Chen Z, Gerhold-Ay A, Gebhard S, et al: Immunoglobulin kappa $C$ predicts overall survival in node-negative breast cancer. PloS One 7: e44741, 2012.

21. Anttila BM, Kosma V, Ji H, et al: Clinical significance of alpha-catenin, collagen IV, and $\mathrm{Ki}-67$ expression in epithelial ovarian cancer. J Clin Oncol 16: 2591-2600, 1998.

22. Schmidt M, Bremer E, Hasenclever D, et al: Role of the progesterone receptor for paclitaxel resistance in primary breast cancer. Br J Cancer 96: 241-247, 2007.

23. Remmele W and Stegner H: Recommendation for uniform definition of an immunoreactive score (IRS) for immunohistochemical estrogen receptor detection (ER-ICA) in breast cancer tissue. Pathologe 8: 138-140, 1987 (In German).

24. Steiner E, Pollow K, Hasenclever D, et al: Role of urokinase-type plasminogen activator (uPA) and plasminogen activator inhibitor type 1 (PAI-1) for prognosis in endometrial cancer. Gynecol Oncol 108: 569-576, 2008.

25. Aune G, Stunes AK, Tingulstad S, Salvesen O, Syversen U and Torp SH: The proliferation markers Ki-67/MIB-1, phosphohistone $\mathrm{H} 3$, and survivin may contribute in the identification of aggressive ovarian carcinomas. Int J Clin Exp Pathol 4: 444-453, 2011.

26. Harlozińska A, Bar JK, Sedlaczek P and Gerber J: Expression of p53 protein and Ki-67 reactivity in ovarian neoplasms. Correlation with histopathology. Am J Clin Pathol 105: 334-340, 1996.

27. Korkolopoulou P, Vassilopoulos I, Konstantinidou AE, et al: The combined evaluation of $\mathrm{p} 27^{\mathrm{Kip} 1}$ and $\mathrm{Ki}-67$ expression provides independent information on overall survival of ovarian carcinoma patients. Gynecol Oncol 85: 404-414, 2002.

28. Kerns BJ, Jordan PA, Faerman LL, Berchuck A, Bast RC Jr and Layfield LJ: Determination of proliferation index with MIB-1 in advanced ovarian cancer using quantitative image analysis. Am J Clin Pathol 101: 192-197, 1994.

29. Silverberg SG: Histopathologic grading of ovarian carcinoma: a review and proposal. Int J Gynecol Pathol 19: 7-15, 2000.

30. Lenhard M, Tereza L, Heublein S, et al: Steroid hormone receptor expression in ovarian cancer: progesterone receptor $\mathrm{B}$ as prognostic marker for patient survival. BMC Cancer 12: 553, 2012.

31. Kommoss F, Pfisterer J, Thome M, Schäfer W, Sauerbrei W and Pfleiderer A: Steroid receptors in ovarian carcinoma: immunohistochemical determination may lead to new aspects. Gynecol Oncol 47: 317-322, 1992.

32. Langdon SP, Hirst GL, Miller EP, et al: The regulation of growth and protein expression by estrogen in vitro: a study of 8 human ovarian carcinoma cell lines. J Steroid Biochem Mol Biol 50: 131-135, 1994.

33. Akahira J, Inoue T, Suzuki T, et al: Progesterone receptor isoforms A and B in human epithelial ovarian carcinoma: immunohistochemical and RT-PCR studies. Br J Cancer 83: 1488-1494, 2000.

34. Kuhn W, Pache L, Schmalfeldt B, et al: Urokinase (uPA) and PAI-1 predict survival in advanced ovarian cancer patients (FIGO III) after radical surgery and platinum-based chemotherapy. Gynecol Oncol 55: 401-409, 1994.

35. Ahlgren JD, Ellison NM, Gottlieb RJ, et al: Hormonal palliation of chemoresistant ovarian cancer: three consecutive phase II trials of the Mid-Atlantic Oncology Program. J Clin Oncol 11: 1957-1968, 1993

36. Papadimitriou CA, Markaki S, Siapkaras J, et al: Hormonal therapy with letrozole for relapsed epithelial ovarian cancer. Long-term results of a phase II study. Oncology 66: 112-117, 2004.

37. Kommoss S, du Bois A, Schmidt D, Parwaresch R, Pfisterer J and Kommoss F: Chemotherapy may be more effective in highly proliferative ovarian carcinomas - a translational research subprotocol of a prospective randomized phase III study (AGO-OVAR 3 protocol). Gynecol Oncol 103: 67-71, 2006. 